\section{Renal anemia and L-carnitine therapy in hemodialysis patients}

Received: Ocotber 25, 2015; Accepted: Ocotber 28, 2015; Published: November 04, 2015

Renal anemia is a common complication in hemodialysis (HD) patients, and resulting mainly from reduced erythropoietin production [1,2]. Renal anemia can result in reduced exercise tolerance, impaired cognition, depression, dyspnea, heart failure and increased mortality in HD patients [1,2]. Erythropoietin therapy is a standard treatment for renal anemia; however, $5-10 \%$ of HD patients show erythropoietin resistance $[1,3]$.

The most common cause of erythropoietin resistance is reduced iron availability, including absolute and functional iron deficiency [2]. Hepcidin, a 25-amino-acid peptide predominantly produced by liver, decreases the release of iron from storage tissues and causes a reduction in iron absorption from the gut (3). Therefore, hepcidin is involved in the pathogenesis of erythropoietin resistance [3]. Inflammation increases hepcidin production, limiting the availability of iron for erythropoiesis and thus providing a direct link between inflammation and erythropoietin resistance [1]. The reduction of inflammation is a reasonable approach for treating erythropoietin resistance.

Carnitine deficiency, like anemia and inflammation, is prevalent in HD patients and causes by low dietary intake, impaired de novo carnitine renal synthesis, and loss of free carnitine from body during hemodialysis [4]. It has been shown that dialysis patients with anemia have lower serum carnitine than nonanemic renal patients and need higher doses of erythropoietin [5]. To date, all studies (i.e. 8 trials) on the effects of L-carnitine supplement on inflammation, except one, showed that L-carnitine could significantly reduce serum inflammation markers in HD patients [6]. In addition, according to available literature, the majority of trials indicated that L-carnitine administration might have a beneficial effect on renal anemia management in dialysis patients. Eight trials showed that

\author{
Hadi Tabibi \\ Department of Clinical Nutrition \& Dietetics, \\ Faculty of Nutrition and Food Technology, \\ National Nutrition and Food Technology \\ Research Institute, Shahid Beheshti \\ University of Medical Sciences, Tehran, \\ Islamic Republic of Iran.
}

\section{Corresponding author: Hadi Tabibi}

Associate Professor (PhD), Department of Clinical Nutrition \& Dietetics, Faculty of Nutrition and Food Technology, National Nutrition and Food Technology Research Institute, Shahid Beheshti University of Medical Sciences, Tehran, 198396-3113, Islamic Republic of Iran.

\section{hadtabibi@yahoo.com}

Tel: 00989122445367

Citation: Tabibi H. Renal anemia and L-carnitine therapy in hemodialysis patients. J Clin Nutr Diet. 2016, 1:1

L-carnitine supplement in dialysis patients increased hemoglobin concentration [7-12] and decreased erythropoietin requirement $[5,9,10]$ or erythropoietin resistance index [13]. However, some studies reported that L-carnitine supplement had no effect on hemoglobin concentration or erythropoietin requirement [1417]. Therefore, L-carnitine supplement can be used as an adjuvant therapy to improve erythropoietin efficiency for the treatment of renal anemia in dialysis patients, especially those with carnitine deficiency or erythropoietin resistance. 


\section{References}

1 Kanbay M, Perazella MA, Kasapoglu B, Koroglu M, Covic A et al. (2010) Erythropoiesis stimulatory agent- resistant anemia in dialysis patients: review of causes and management. Blood Purif 29:1-12.

2 Golper TA, Goral S, Becker BN, Langman (2003) CB L-carnitine treatment of anemia. Am J Kidney Dis 41: S27-S34.

3 Yilmaz MI, Solak Y, Covic A, Goldsmith D, Kanbay M (2011) Renal anemia of inflammation: the name is self-explanatory. Blood Purif 32: $220-225$.

4 Evans A. (2003) Dialysis-related carnitine disorder and levocarnitine pharmacology. Am J Kidney Dis 41: S13-S26.

5 Labonia WD. (1995) L-carnitine effects on anemia in hemodialyzed patients treated with erythropoietin. Am J Kidney Dis 26: 757-764.

6 Khalatbari-Soltani S, Tabibi H (2015) Inflammation and L-carnitine therapy in hemodialysis patients: a review. Clin Exp Nephrol 19: 331-335.

7 Savica V, Santoro D, Mazzaglia G, Ciolino F, Monardo P, Calvani M, Bellinghieri G, Kopple JD et al. (2005) L-Carnitine Infusions May Suppress Serum C-Reactive Protein and Improve Nutritional Status in Maintenance Hemodialysis Patients. J Ren Nutr 15: 225-230.

8 Mitwalli AH, Al-Wakeel JS, Alam A, Tarif N, Abu-Aisha H, Rashed M, Al Nahed $\mathrm{N}$ et al. (2005) L-carnitine supplementation in hemodialysis patients. Saudi J Kidney Dis Transplant 16: 17-22.

9 Wanic-Kossowska M, Kaźmierski M, Pawliczak E, Kobelski M. (2007) Combined therapy with L-carnitine and erythropoietin of anemia in chronic kidney failure patients undergoing hemodialysis. Polskie Archiwum Medycyny Wewnetrznej 117: 1-5

10 Di lorio BR, Guastaferro P, Cillo N, Cucciniello E, Bellizzi V (2007) Long- term L-carnitine administration reduces erythropoietin resistance in chronic hemodialysis patients with thalassemia minor. Drug Target Insights 2: 1-7.

11 Naini $A E$, Moradi $M$, Mortazavi $M$, Harandi $A A$, Hadizadeh $M$, Shirani F, Ghafoori HB, Naini PE (2012) Effects of oral L-carnitine supplementation on lipid profile, anemia, and quality of life in chronic renal disease patients under hemodialysis: a randomized, doubleblinded, placebo-controlled trial. J Nutr Metab 2012: 510483.

12 Trovato GM, Gingardi V, Di Macro V, Dell'Aira A, Corsi M (1982) Longterm L-carnitine treatment of chronic anemia of patients with endstage renal failure. Curr Ther Res 31: 1042-1049.

13 Kletzmayr J, Mayer G, Legenstein E, Heinz-Peer G, Lettha T, Horl WH, Kovarik J (1999) Anemia and carnitine supplementation in hemodialyzed patients. Kidney Int 55: S93-S106.

14 Caruso U, Leone L, Cravotto E, Nava D (1998) Effects of L-carnitine on anemia in aged hemodialysis patients treated with recombinant human erythropoietin: a pilot study. Dial Transplant 27: 498-506.

15 Verrina E, Caruso U, Calevo MG, Emma F, Sorino P, De Palo T, Lavoratti G, Dertenois LT, Cassanello M, Cerone R, Perfumo F (2007) Effect of carnitine supplementation on lipid profile and anemia in children on chronic dialysis. Pediatr Nephrol 22: 727-733.

16 Mercadal L, Coudert M, Vassault A, Pieroni L, Debure A, Ouziala M, Depreneuf H, Fumeron C, Servais A, Bassilios N, Be'cart J, Assogba, Allouache M, Bouali B, Luong N, Dousseaux MP, Montcel ST, Deray G (2012) L-carnitine treatment in incident hemodialysis patients: the multicenter, randomized, double-blinded, placebo-controlled CARNIDIAL trial. Clin J Am Soc Nephrol 7: 1836-1842.

17 Sabry AA (2010) The role of oral L-carnitine therapy in chronic hemodialysis patients. Saudi J Kidney Dis Transpl 21: 454-459. 